\title{
Current Employee's Stability and Job Satisfaction: As a Part of Project Success in Construction Industry
}

\section{With Special Reference to Ahmedabad City}

\author{
Shivani K. Patel \\ Student, Department of Civil Engineering \\ L.J Institute of Engineering and Technology \\ Gujarat, India \\ Preet D. Patel \\ Student, Department of Civil Engineering \\ L.J Institute of Engineering and Technology \\ Gujarat, India
}

\author{
Chinmay Y. Patel \\ Student, Department of Civil Engineering \\ L.J Institute of Engineering and Technology \\ Gujarat, India \\ Prof. Vismay Shah \\ Faculty, Department of Civil Engineering \\ L.J Institute of Engineering and Technology \\ Gujarat, India
}

\begin{abstract}
This study is about job satisfaction and its effect on employee's stability which eventually accounts to a successful project. The construction sector is advancing at a faster pace and has a remarkable impact on economic trend of a country. The general objective of this study is to find out level of satisfaction from the perspective of the stakeholders such as builders, contractor, HR manager and site-engineer. And the specific objective is to analyses sand acquire better understanding of the factors that affect their stability and satisfaction at work place and establish a significant relation between them. For the study, a sample of 30 respondents was taken selected from small as well as big reputed construction firms of Ahmedabad city. Questionnaire survey was conducted and data was analyzed using Relative Importance Index method. The major issues founded which should be focused immediately for better results are Superior's Criticism, Level of Recognition, Procedures to make A difficult Job Easier. Probable conclusion based on the major 3 causes that will help the company owners to keep their employees engaged and stable for a long duration and an overview based on their answers is given in this study.
\end{abstract}

Keywords- Employee's satisfaction, job stability, project success, Relative Reflective Index, Questionnaire survey.

\section{I.INTRODUCTION}

In today's time, India holds the second position as fastest growing economy in the world. In the world of technology where everything can be imitated, the only unique factor is the employ of the organization[1]."The growth rate of the construction industry across India was estimated to be $5.65 \%$ from fiscal year 2015 to 2020 ,up from about $2.95 \%$ from 2010 to fiscal year 2015.In January 2019, India's construction sector has a contribution of over 2.7 trillion Indian rupees to country's GDP'[2].Construction in developing countries is mostly labor oriented with basic tools and machineries. Along with other characteristics, it can also be known for giving employment to maximum labor force as it consists of job demanding different skill levels. Hence it can be concluded that excessive employee turnover can be troublesome not just for the organizations but also for customers as they take away great degree of collected skills and knowledge, also substitution of an employ is expensive and the disturbance caused in schedule and management of a project can be very high. In the past, a lot of study has been done on job satisfaction in different fields but construction industry is less explored.

\section{What is Job Satisfaction or Employee's Satisfaction?}

Employment satisfaction is a measurable degree of an employee's positive or negative emotional attachment to their job, colleagues and organization that profoundly influences their willingness to learn and perform at work.[3]

\section{What is Job Stability or Employee's Stability?}

Job Stability refers to the stability that one has in her or his job or occupation. Job Stability can also be understood as the duration one perceives to keep his or her current job without external factors.[4]

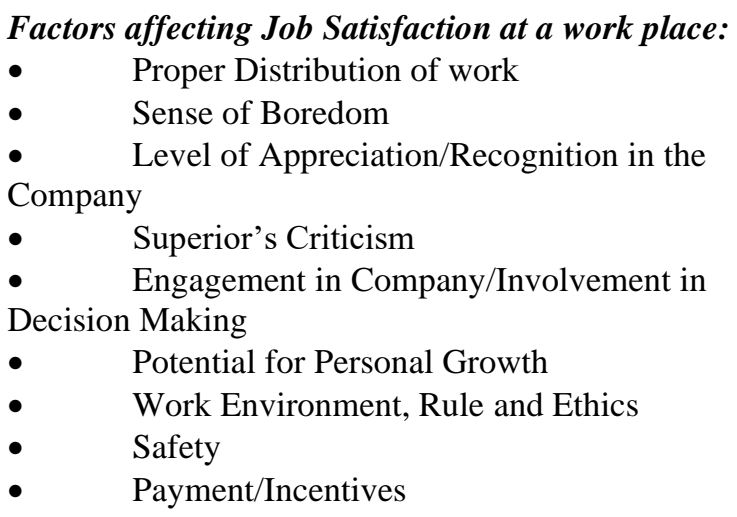

These 9 major factors were filtered out and derived from different literature papers and based on these factors the questions were prepared to be surveys. 
1. Proper Distribution of Work

2. Sense of Boredom

3. Level of Appreciation/ Recognisation in the Company

4. Superior's Criticism

5. Engagement in the Company

6. Potential for Personal Growth

7. Work Environment, Rule and Ethics

8. Safety

9. Payment/Incentives

Figure 1. Factors leading to project success through Job Satisfaction and Employee's Stability

\section{METHODOLOGY}

1. Data Collection.

- The questionnaire survey consisted of two part, in the former one the respondents were asked to answer general questions namely, their name, sex, position in company etc. whereas; in the latter part they answered 18 questions derived from the above listed factors affecting satisfaction and other general factors, for determining their level of satisfaction in the company.

- The data was collected by performing questionnaire survey taken by professionals such as senior engineer (9), junior engineers (8), company owners (Builders) (11) and HR managers (2) from 19 companies.

- $\quad$ For efficient analysis, 4-Point Likert scale was used in case to avoid neutral opinion where $1=$ Very low, 2=Low, 3=High, 4=Very high are the weightages given to them.

\section{Data Analysis}

The analysis is done by Relative Importance Index (RII) for signifying rank to factor affecting their job satisfaction and stability.

$R I I=\Sigma W /(A \times N) ; \sum W=4 n_{4}+3 n_{3}+2 n_{2}+1 n_{1}[5]$

where,

$\mathrm{n}_{1}=$ No of respondent very low,

$\mathrm{n}_{2}=$ No. of respondent low,

$\mathrm{n}_{3}=$ No. of respondent high,

$\mathrm{n}_{4}=$ No. of respondent very high,

$\mathrm{W}=$ Weightage given to each factor by the respondents,

$\mathrm{A}=$ Highest weight (i.e., 4 in this case),

$\mathrm{N}=$ the total number of respondents (i.e., 30 in this case).

The analysis by RII method is done in Excel.

\section{FIRST SECTION}

\section{ESULTS AND DISCUSSION}

- In first section of the questionnaire, general information was asked from the respondents regarding their info, company's name, position in company, level of education, tenure of service and department he/she is working in currently. The respondent level of education, position in company and tenure of service are shown in the Figure 1.

\section{Position in company}

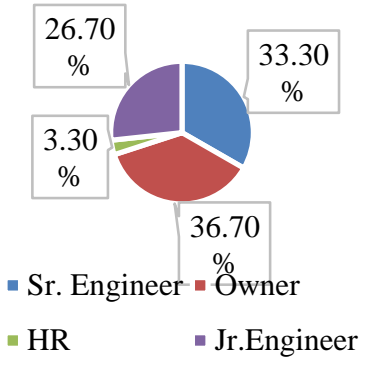

Tenure of Services

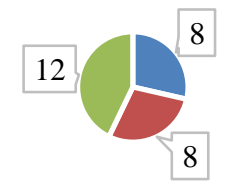

- Less than 2 years

- 2 to 5 years

- Greater than 5 years

\section{Level of Education}

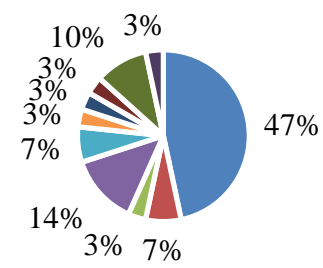

$\begin{array}{ll}=\text { B.E. Civil Engineering } & =\text { Graduate } \\ =\text { MBA } & \text { - Diploma in Civil } \\ =\text { Post Graduation } & =\text { M. Com } \\ - \text { B. Com } & - \text { MHRM }\end{array}$

Figure 2. Respondent level of education, nosition in comnanv and tenure

\section{SECOND SECTION}

- In the second part two tables were prepared. Table 1 shows RII factor corresponding to each question along with total respondents and weighted total and Table 2 shows top 5 factors with maximum RII index along with number of responses given to each option.

- Out of the important 9 factors, it is very evident that Safety, Personal Growth, Distribution of Work, Involvement in decision making were rated as highest frequency factors above 0.8 RII Index.

- $\quad$ From the collected sample of respondents, questions referring to causes such as superior's criticism, Level of Recognition, Procedures to make difficult job easy and likeliness of switching the job for better payment were rated as lowest frequency factors below $0.8 \mathrm{RII}$ Index. 
- Other aspects which include co-operation of coworkers, Work Load, Payment and Incentives, Work Environment were mediumly marked.

Table 1 RII calculation

\begin{tabular}{|c|c|c|c|c|c|c|c|}
\hline \multicolumn{8}{|c|}{ For each item, enter the frequency with which each response option was observed: Computed values, given the 4 frequency entries: } \\
\hline Factor & $\begin{array}{l}\text { Frequency of } \\
\text { "Very High" } \\
\text { responses }\end{array}$ & $\begin{array}{c}\text { Frequency of } \\
\text { "High" responses }\end{array}$ & $\begin{array}{c}\text { Frequency of "Low" } \\
\text { responses }\end{array}$ & $\begin{array}{c}\text { Frequency of "Very Low" } \\
\text { responses }\end{array}$ & $\begin{array}{c}\text { Total respondents } \\
(\mathrm{N})\end{array}$ & $\begin{array}{l}\text { Weighted } \\
\text { total }\end{array}$ & RII \\
\hline 1 & 5 & 16 & 7 & 1 & 29 & 83 & 0.716 \\
\hline 2 & 10 & 17 & 3 & 0 & 30 & 97 & 0.808 \\
\hline 3 & 2 & 5 & 12 & 10 & 29 & 57 & 0.491 \\
\hline 4 & 3 & 21 & 0 & 4 & 28 & 79 & 0.705 \\
\hline 5 & 5 & 14 & 4 & 5 & 28 & 75 & 0.670 \\
\hline 6 & 12 & 13 & 3 & 1 & 29 & 94 & 0.810 \\
\hline 7 & 14 & 12 & 4 & 0 & 30 & 100 & 0.833 \\
\hline 8 & 10 & 17 & 1 & 2 & 30 & 95 & 0.792 \\
\hline 9 & 13 & 11 & 5 & 1 & 30 & 96 & 0.800 \\
\hline 10 & 8 & 19 & 3 & 0 & 30 & 95 & 0.792 \\
\hline 11 & 4 & 5 & 11 & 8 & 28 & 61 & 0.545 \\
\hline 12 & 6 & 18 & 6 & 0 & 30 & 90 & 0.750 \\
\hline 13 & 15 & 14 & 1 & 0 & 30 & 104 & 0.867 \\
\hline 14 & 7 & 14 & 5 & 2 & 28 & 82 & 0.732 \\
\hline 15 & 7 & 18 & 4 & 1 & 30 & 91 & $\begin{array}{l}0.758 \\
\end{array}$ \\
\hline 16 & 5 & 18 & 6 & 1 & 30 & 87 & \begin{tabular}{|l}
0.725 \\
\end{tabular} \\
\hline 17 & 11 & 15 & 4 & 0 & 30 & 97 & \begin{tabular}{|l}
0.808 \\
\end{tabular} \\
\hline 18 & 10 & 13 & 5 & 2 & 30 & 91 & $\mathbf{0 . 7 5 8}$ \\
\hline
\end{tabular}

Table 2 Highest Frequency Factors

\begin{tabular}{|c|c|c|c|c|c|c|c|}
\hline $\begin{array}{l}\text { Top } 5 \\
\text { Factors }\end{array}$ & $\begin{array}{l}\text { Frequency } \\
\text { of "Very } \\
\text { High" } \\
\text { responses }\end{array}$ & $\begin{array}{l}\text { Frequency } \\
\text { of "High" } \\
\text { responses }\end{array}$ & $\begin{array}{l}\text { Frequency } \\
\text { of "Low" } \\
\text { responses }\end{array}$ & $\begin{array}{l}\text { Frequency } \\
\text { of "Very } \\
\text { Low" } \\
\text { responses }\end{array}$ & $\begin{array}{l}\text { Total } \\
\text { respondents } \\
(\mathrm{N})\end{array}$ & $\begin{array}{l}\text { Weighted } \\
\text { total }\end{array}$ & RII \\
\hline 13 & 15 & 14 & 1 & 0 & 30 & 104 & 0.867 \\
\hline 7 & 14 & 12 & 4 & 0 & 30 & 100 & 0.833 \\
\hline 6 & 12 & 13 & 3 & 1 & 29 & 94 & 0.810 \\
\hline 2 & 10 & 17 & 3 & 0 & 30 & 97 & 0.808 \\
\hline 17 & 11 & 15 & 4 & 0 & 30 & 97 & 0.808 \\
\hline
\end{tabular}

\begin{tabular}{|c|c|c|c|c|c|c|c|}
\hline $\begin{array}{l}\text { Bottom } 5 \\
\text { Factors }\end{array}$ & $\begin{array}{l}\text { Frequency of } \\
\text { "Very High" } \\
\text { responses }\end{array}$ & $\begin{array}{l}\text { Frequency of } \\
\text { "High" } \\
\text { responses }\end{array}$ & $\begin{array}{c}\text { Frequency of } \\
\text { "Low" } \\
\text { responses }\end{array}$ & $\begin{array}{c}\text { Frequency of } \\
\text { "Very Low" } \\
\text { responses }\end{array}$ & $\begin{array}{c}\text { Total } \\
\text { respondents }(\mathrm{N})\end{array}$ & $\begin{array}{l}\text { Weighted } \\
\text { total }\end{array}$ & RII \\
\hline 3 & 2 & 5 & 12 & 10 & 29 & 57 & 0.491 \\
\hline 11 & 4 & 5 & 11 & 8 & 28 & 61 & 0.545 \\
\hline 5 & 5 & 14 & 4 & 5 & 28 & 75 & 0.67 \\
\hline 4 & 3 & 21 & 0 & 4 & 28 & 79 & 0.705 \\
\hline 1 & 5 & 16 & 7 & 1 & 29 & 83 & 0.716 \\
\hline
\end{tabular}

Table 3 Lowest Frequency Factors 
- It can be seen that majority of the respondents agree to the fact that Employee's Stability is majorly influenced by their Job Satisfaction.

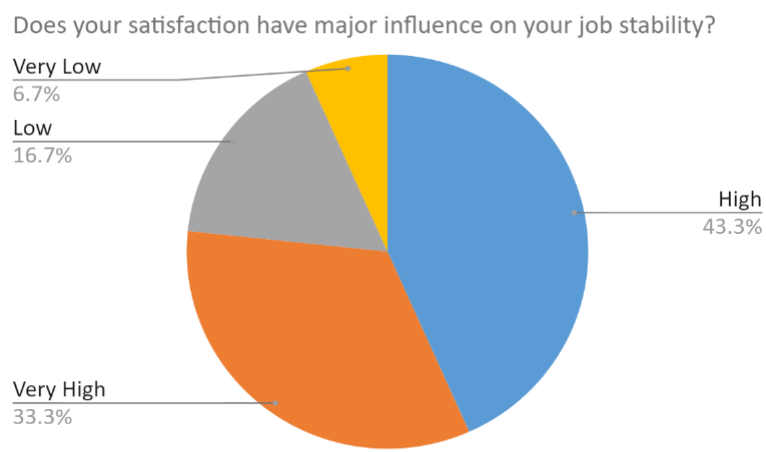

Figure 3. Influence of satisfaction on job stability

- Along with that, most of the respondent agree to the fact that Job satisfaction and stability has a vital influence on their performance. Hence, their good or bad performance will eventually reflect on success or failure of the entire project.

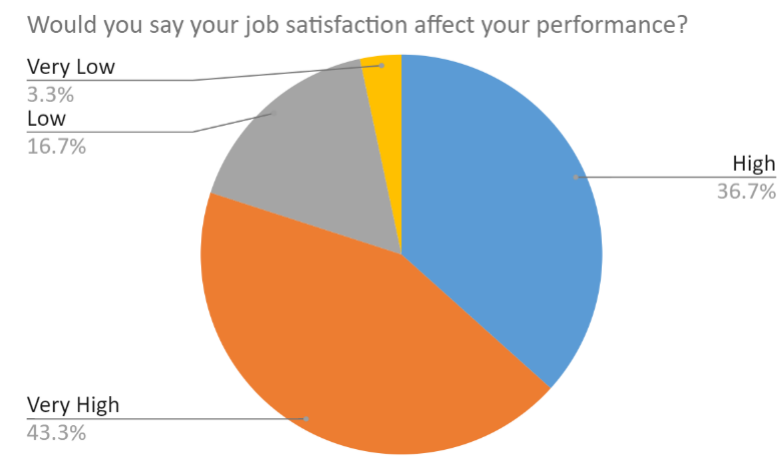

Figure 4. Effect of job satisfaction on Performance

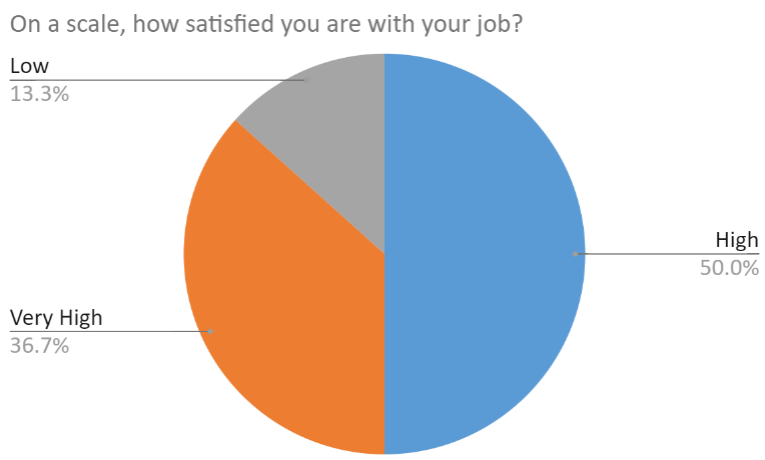

Figure 5. Level of Satisfaction

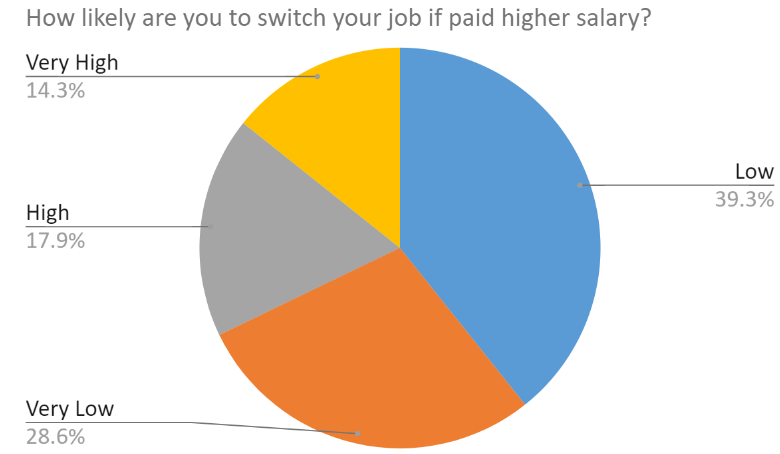

Figure 6. Willingness to switch the job

- From the data, it can be correctly believed that most of the respondent have a great sense of satisfaction, thus rate of employees willing to switch their job if paid higher is less comparatively.

\section{CONCLUSION}

- Overall, to put an end to this pressing issue of employee turnover, the owners need to take care of their employees' need and all the above listed factors should be fulfilled in order to keep the staff happy and motivated.

- The company owners can work upon factors which have received moderate RII Index in order to get better results for the company from their employees. Also, from the above analysis the three factors which need to be focused immediately are superior's criticism, Level of Recognition and Procedures to make a difficult job easy. Owners must find an effective way to communicate and educate their employees about their mistake without demeaning them. Respecting, rewarding and acknowledging their employees' work will keep them engaged and motivated which will lessen their willingness to leave their job. And lastly, guidelines and facilities to ease up difficult job and passing on wisdom of experience may help them become more confident and in personal growth.

\section{BIBLIOGRAPHY}

\section{References}

[1] University of Tanzania. (2015). JOB SATISFACTION AMONG WORKERS IN THE CONSTRUCTION INDUSTRY: A CASE OF NATIONAL HOUSING CORPORATION. Retrieved from http://repository.out.ac.tz/1321/1/DISSERTATION__NGONDE_FINAL_1.pdf

[2] India - growth rate of construction industry 2010-2020 | Statista.

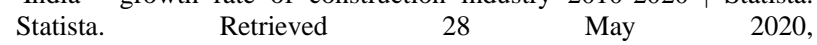
from https://www.statista.com/statistics/878482/india-growth-rate-ofconstruction-industry/.

[3] Karthikeyan, P \& Devi, N \& Mirudhubashini, J. (2013). A STUDY ON EMPLOYEE ENGAGEMENT IN CONSTRUCTION FIRMS WITH SPECIAL REFERENCE TO COIMBATORE CITY. International Journal of Human Resource Management and Research (IJHRMR). 3. $17-26$.

[4] Job Stability Definition | Human Resources (HR) Dictionary | MBA Skool-Study.Learn.Share.. (2017). Retrieved 28 May 2020, from https://www.mbaskool.com/business-concepts/human-resourceshr-terms/16945-job-stability.html.

[5] Bhojak, S., \& Shah, V. (2019). Ethical Issues in Construction Industry (p. 52). Lambert Academic Publishing. 
Copy of questionnaire of the Current Employee's

Stability and Job Satisfaction: As a Part of Project

Success in construction industry

\begin{tabular}{|c|}
\hline 1. Procedures to make difficult job easy \\
\hline$\square$ Very High $\square$ High $\square$ Low $\square$ Very Low \\
\hline 2. Proper distribution of work \\
\hline$\square$ Very High $\square$ High $\square$ Low $\square$ Very Low \\
\hline 3. Frequency of sense of boredom in work \\
\hline Very High $\square$ High $\square$ Low $\square$ Very Low \\
\hline
\end{tabular}

4. Level of appreciation/recognition/promotion by higher authority

$\square$ Very High $\quad \square$ High $\square$ Low $\square$ Very Low

5. How efficiently you take your superior's criticism?

$\square$ Very High $\quad \square$ High $\square$ Low $\square$ Very Low

6. How much are you involved in decision making?

$\square$ Very High $\quad \square$ High $\quad \square$ Low $\square$ Very Low

7. Do you find your job meaningful and see your personal advancement in this company?

$\square$ Very High $\quad \square$ High $\quad \square$ Low $\quad \square$ Very Low

8. How well do your co-workers co-operate or comments on team work in your company?

$\square$ Very High $\quad \square$ High $\square$ Low $\square$ Very Low

9. Would you say your job satisfaction affect your performance?

$\square$ Very High $\quad \square$ High $\quad \square$ Low $\square$ Very Low

10 . Would you say your result affect your performance?

$\square$ Very High $\quad \square$ High $\quad \square$ Low $\square$ Very Low

11. How likely are you to switch your job if paid higher salary?

$\square$ Very High $\quad \square$ High $\quad \square$ Low $\quad \square$ Very Low

12. How would you describe your work load?

$\square$ Very High $\quad \square$ High $\quad \square$ Low $\quad \square$ Very Low

13. How socially safe you feel in your company?

$\square$ Very High $\quad \square$ High $\quad \square$ Low $\square$ Very Low

14. How satisfied are you with incentives/pay in your company?

$\square$ Very High $\quad \square$ High $\quad \square$ Low $\quad \square$ Very Low

15. How do you feel about rules/working environment in your company?

$\square$ Very High $\quad \square$ High $\quad \square$ Low $\quad \square$ Very Low

16. Does the purpose of the company align with you own goal? Or is this what you always wanted to do?

$\square$ Very High $\quad \square$ High $\quad \square$ Low $\quad \square$ Very Low

17. On a scale, how satisfied you are with your job?

$\square$ Very High $\quad \square$ High $\quad \square$ Low $\quad \square$ Very Low

18. Does your satisfaction have major influence on your job stability?

$\square$ Very High $\quad \square$ High $\quad \square$ Low $\quad \square$ Very Low 